\title{
TRANSFORMATION OF THE LEARNING PROCESS IN HIGHER EDUCATION INSTITUTIONS UNDER THE INFLUENCE OF THE PANDEMIC COVID-19
}

DOI: $10.36740 /$ WLek202106140

\author{
Halyna 0. Vaskivska', Svitlana P. Palamar', Nataliya V. Kravtsova², Olha V. Khodakivska² \\ 'PEDAGOGICAL INSTITUTE, BORYS GRINCHENKO KYIV UNIVERSITY, KYIV, UKRAINE \\ ${ }^{2}$ BOGOMOLETS NATIONAL MEDICAL UNIVERSITY, KYIV, UKRAINE
}

\begin{abstract}
The aim: To analyze the challenges and approaches used in medical universities in different countries during the transfer of training from offline to online format during the COVID-19 pandemic.

Materials and methods: Electronic databases of Scielo, Scopus and PubMed were searched using keyword searches.

Conclusions: The use of a large number of online tools and ICTs to develop the clinical skills of medical students has become a real pedagogical breakthrough in medical education. Innovations and technological efficiency of educational tools will change medical education forever. But it is difficult to give an unambiguous assessment of the delayed effects of these changes, since not much is yet known about the long-term impact of COVID-19 on the medical education.
\end{abstract}

KEY WORDS: education, medical education, COVID-19, online learning, distance learning

Wiad Lek. 2021;74(6):1505-1509

\section{INTRODUCTION}

There is no doubt that 2020 was a period of rethinking the usual ideas about approaches in the education system. The main driver of this process was the outbreak of the COVID-19 pandemic, announced by the World Health Organization on March 11, 2020 [1]. Quarantine measures, restrictions on movement in cities, between cities and countries, mandatory self-isolation, social distance and other measures to prevent the spread of the SARS$\mathrm{CoV}-2$ virus have come into effect in countries around the world. The COVID-19 pandemic has become a real health crisis with huge and diverse social, economic and medical consequences [2].

Taking into consideration that the social isolation is the most important strategy used in this emergency, changes have taken place in all social areas, including the education and the medical education in particular. Most educational institutions have faced difficulties related to the need to come over to distance learning. In addition to educational institutions, the COVID-19 pandemic has also led to the disruption of the working hours of hospitals, medical services, laboratories and other important educational environments for medical students [3]. The complete abolition of classroom studies and their replacement with distance learning has raised many questions about the conduct of training in preclinical and clinical disciplines, and, as a result, questions about the quality of the medical education [4].
The widespread and daily use of modern distance learning platforms and the latest interactive learning technologies has become a new norm for medical education institutions. Most institutions switched to distance learning in the simplest, most convenient, and most cost-effective ways, including using conference platforms, email, and telephone communication. It should be noted that in general, information and communication technologies (ICTs) in the medical education are not something new and unusual that COVID-19 has brought, since they have been used here since the end of the XX century, with a lot of research in this direction, protocols and pedagogical debate about the use of these tools [5]. However, ICT is not a resource used in all sectors of medical education, as a personalized learning model focused on the content and development of clinical skills still prevails in the medical education [6].

The pandemic has forced teachers from around the world to rethink all the possibilities of using online learning technologies and ICTs in the medical education, as well as analyze how existing resources of educational institutions can contribute to the rapid transformation of the conservative and specific medical education. All these changes will forever leave their mark on the system of medical education and the education in general, and, at this stage, the medical community can only guess and predict what delayed consequences of these changes may await society in the near future. 


\section{THE AIM}

The aim of the article is to analyze the challenges faced by medical universities during the transfer of training in medical educational institutions from offline to online format during the COVID-19 pandemic; to review the approaches, tools and technologies used in different countries in order to transform the training process of future doctors.

\section{MATERIALS AND METHODS}

Analysis of 24 literature sources containing information on the main challenges in the transition to online learning and technologies used in the restructuring of the educational process in medical education institutions in the context of the COVID-19 pandemic in different countries of the world. The search for literary sources was carried out in four main scientific databases: Scopus, PubMed, BVS, Scielo. The review included original articles, research, and official recommendations from medical associations.

\section{REVIEW AND DISCUSSION}

In response to the pandemic, most medical universities have begun to change rapidly the learning process to move from an offline to an online format. The medical education has its own specifics, and this is due to the fact that the formation of most of the clinical competencies of a future doctor is inextricably linked with forms of training that require the student's personal presence in the educational environment. These are, first of all, communication skills that are developed through direct interaction of students with patients, the skills of collecting an anamnesis of the disease, and various practical manipulations that form the clinical competencies of the future doctor. Medicine has long been a conservative science, and historically the medical community has not supported the use of distance learning technologies in medical education. However, in the face of the COVID-19 pandemic, everyone found themselves in the same conditions and with almost the same goals, tasks and challenges.

\section{THE MOST COMMON PROBLEMS OF THE PASSING TO THE ONLINE FORMAT}

There were two main predictions about the potential impact of the COVID-19 pandemic on online education. Some experts believed that the COVID-19 pandemic would negatively affect online education for a number of reasons [7]. A separate factor that influenced the quality of online learning in self-isolation was being at home. Teachers and students may be distracted by children or siblings who also don't go to school. Online education can be unequal in terms of access and quality of teaching: some students do not have laptops or high-speed Internet at home, older users of the Internet and computer programs are most affected by online education for reasons such as technophobia [8]. All of the above factors are the basis for the first point of view that the pandemic will negatively affect the formation and qualitative development of online education in medicine.
Among the main challenges that have been identified by the medical community in the process of transforming curricula into an online format based on the results of many studies, the following can be distinguished: 1) communication; 2) conducting an assessment; 3) using technological programs and services; 4) working online; 5) tension and stress associated with the pandemic; 6) Time Management; 7) technophobia [9].

In contrast, there is another, opposing view that the COVID-19 pandemic will have a positive impact on online education and lead to greater use and recognition of online education and ICT in medical education in the post-covid period. Long before COVID-19, there was already a high growth and introduction of educational technologies in the process of training doctors [10]. Proponents of this view believe that with the right approach, online medical education can be just as effective as traditional classroom learning [11]. This opinion is also supported by colleagues from the University of Edinburgh, in their article they note that online learning is not inferior to the offline format [12]. Certainly, with such a sudden transition, most teachers try to preserve the established teaching methods and styles as much as possible, since there is absolutely no time for a systematic review of curricula and methods. However, do not think that simply transferring educational content online (videos, presentations, or lecture texts) will have the same effect as in the audience. After all, interactive learning in offline and online format requires different approaches and tools, as well as different competencies of the teacher.

We analyzed the experience of some countries around the world in order to determine the resources and technologies that were used in the transformation of the educational process of medical educational institutions.

\section{CHINA'S EXPERIENCE}

China was the first country to be affected by the virus wave. In China, there are more than 200 medical education institutions of various levels. They actively used online technologies, Virtual reality modeling Language techniques (VRML) and 3D animation for educational practice even before the pandemic, but during the pandemic in China, the use of services for synchronous and asynchronous learning increased significantly. During synchronous learning, students and teachers interact in real time usind different teleconferencing platforms (Zoom, WEBEX, Google Meet etc). In parallel, asynchronous learning tools were used (Moodle and Blackboard). They allow teachers and students to stay with them at different times.

The pandemic has raised the importance of the medical education for China's national security and strategic reform of the medical education system as a whole has become a significant focus for China [13].

\section{EXPERIENCE OF THE UNITED ARAB EMIRATES}

The United Arab Emirates is an example of the development and introduction of innovative technologies in online medical training. Specialists of the University of Medicine and healthcare science in Dubai have implemented a pilot 
project to teach communication skills online [14].

Without a doubt, communication skills are an integral part of a doctor's daily practice and is a key factor in patient-centered medicine [15]. Usually, communication skills were formed by students intuitively during training at clinical bases, during daily rounds, and working at the patient's bedside. But pandemy contributed to the appearance of "patient-replacing" technologies.

The most well-known among such technologies are simulated and standardized patients (SP) [16]. The traditional SP technique involves face-to-face communication between SP and clinical training with direct verbal and often tactical contact. In the conditions of quarantine and distance learning, it seemed that this technology would not find a place. But, in Dubai, colleagues managed to use these technologies online. The results of the research showed that the majority $(90 \%)$ of students rated this format of training as effective, the goals of the lesson were achieved and there were no technical difficulties in its implementation. In addition, this approach has proven to be cost-effective, so it is planned to further improve it and widely use it in the process of training medical students.

\section{EXPERIENCE OF THE UNITED STATES OF AMERICA}

The COVID-19 pandemic has provided medical education institutions in the United States with the opportunity to include telemedicine in their curricula in a timely and practical manner. Unlike "patient replacement" technologies, telemedicine allows to communicate with a real patient remotely. The World Health Organization has identified telemedicine as an important tool during the COVID-19 pandemic [17].

The main goals of using telemedicine in medical education are: promoting the assimilation of basic knowledge, improving the decision-making process, improving the perception at anatomy lessons, improving coordination of skills, training on examples of rare or critical clinical cases [18].

The use of telemedicine is quite wide, but it is for medical education institutions that the following areas are most relevant: 1) telesurgery, 2) telehabilitation, 3 ) tele-intensive therapy, 4) treatment of chronic diseases [19].

The American Medical Association encourages the use of telemedicine for medical education and promotes the wider implementation of this tool in the US medical education system. According to a survey by the committee on medical education, more than a quarter of medical universities have already implemented telemedicine components in the preclinical phase of their curricula (the first years of study), and almost half of institutions have implemented telemedicine at the internship stage (the last years of study) [20].

It is also important to note the experience of active use of virtual reality simulation technologies in medical universities in the USA and England [21]. These are technologies that are often based on artificial intelligence algorithms and are able to model the environment in which participants in the educational process feel like in real life [22].

\section{EXPERIENCE OF UKRAINE}

Since March 2020, all universities in Ukraine have passed to distance learning, as preserving students' health is a priority issue of national significance, a common task of society [23]. At the time of the transition from offline to online training, medical universities in Ukraine faced challenges that were relevant for most countries of the world. The primary focus on this way was to increase the level of competence of teachers in the use of tools for online learning and the principles of translating offline training courses into programs for an online format. A number of projects were implemented aimed at exchanging experience and best practices between universities on the organization of distance learning. Thus, Bukovina State Medical University and Kharkiv National Medical University held a series of webinars, where they shared their experience in organizing final exams in a distance format and the features of creating distance learning courses on the MOODLE platform.

Department of pharmacology of the A. A. Bogomolets National Medical University during the pandemic, opened a state-of-the-art pharmacological intelligent training studio, which, due to its properties, is effective for both online and offline training of the discipline "Pharmacology". The technical equipment of the interactive studio is able to ensure full immersion of students in the virtual space of Pharmacology, ensure the formation and development of cognitive abilities and logical thinking. The studio is equipped with 3D models, led circuits, an electronic knowledge control system and analytics. In the context of distance learning, the studio's SMART system allows you to conduct interactive classes with initial knowledge control for 200 students simultaneously, and develop pharmacological/ clinical thinking in medical students without interaction between students and the teacher in the classroom [24].

Although, so far in Ukraine, no thorough research has been conducted on how exactly distance learning takes place in medical universities during the pandemic, but given the trends, it can be noted that the future of medical education in Ukraine will consist in the active introduction of ICT in the study of both preclinical and clinical disciplines.

Transformation of the learning process in medical universities is a complex and multi - stage process. Under the influence of the COVID-19 pandemic, it is important to implement such a transformation in compliance with the following steps:

1. Determination of priorities in the medical education during a pandemic.

2. Correction of the content of educational programs if necessary.

3. Evaluation of available services for widespread use in online learning.

4. Professional development of teachers (technical literacy, creation of distance learning courses, etc.).

5. Identify current problems in online education and find appropriate solutions.

6. Analysis of innovative technologies and approaches used in online medical education, exchange of experience. 
7. Conducting a predictive analysis of the long-term impact of the pandemic on the further development of the medical education.

\section{CONCLUSIONS}

Despite the different points of view of the medical community on distance learning in medicine, it can be argued that it can still be interesting, exciting, effective and safe in a pandemic. Now, more than ever, the opportunities that modern technologies provide us with come to the fore, and we should not ignore them. There is no doubt that all the difficulties and challenges on the way to transforming the educational process encourage teachers to learn new things, develop relevant competencies and look at medical education from a different angle.

The use of a large number of online tools and ICTs to develop the clinical skills of medical students has become a real pedagogical breakthrough in medical education institutions, despite the different attitudes of both teachers and students towards them. While many will remember the COVID-19 pandemic as a source of disruption, it is likely that it will also be assessed as a catalyst for the transformation of the medical education, which, thanks to the pandemic, will become less conservative and open to the use of new modern technologies.

It is already obvious that innovations, the technological efficiency and flexibility of educational tools will change medical education forever. But at the moment, it is difficult for the medical community and society to give an unambiguous assessment of the delayed effects of these changes, since not much is yet known about the long-term impact of COVID-19 on the medical education. Therefore, it is important to record and study the detailed and complete scope of changes that occur. Reassessment of the complex of all these changes can significantly affect the attitude of society to medical education as a strategic direction in the health care system, on which the health of humanity in the future and the national security of each country depends.

\section{REFERENCES}

1. World Health Organization. WHO Director-General's opening remarks at the media briefing on COVID-19-11 March 2020. Geneva, Switzerland: World Health Organization; 2020. https://www.who.int/ $\mathrm{dg} / \mathrm{speeches/detail/who-director-general-s-opening-remarks-at-the-}$ mediabriefingon-covid-19---11-march-2020.

2. Varga Z., Flammer A.J., Steiger P. et al. Endothelial cell infection and endotheliitis in COVID-19. Lancet. 2020; 395:1417-8. doi: 10.1016/ S0140-6736(20)30937-5.

3. Ferrel M.N., Ryan J.J. The impact of Covid-19 on medical education. Cureus. 2020;12(3):e7492. doi: 10.7759/cureus.7492.

4. Ross D.A. Creating a "Quarantine Curriculum" to Enhance Teaching and Learning During the COVID-19 Pandemic. Academic Medicine. 2020. doi.org/10.1097/ACM.

5. Chao L.W., Silveira P.S., Böhm G.M. Telemedicine and education in Brazil. J Telemed Telecare. 1999;5:137-8. doi: 10.1258/1357633991933350.

6. Ellaway R., Masters K. AMEE Guide 32: e-learning in medical education Part 1: learning, teaching and assessment. Med Teach. 2008;30:455-73. doi: 10.1080/01421590802108331.
7. 'Panic-gogy': teaching online classes during the coronavirus pandemic. 2020. https://www.npr.org/2020/03/19/817885991/panic-gogyteaching-online-classes-during-the-coronavirus-pandemic 2020 .

8. How does the pandemic affect U.S. college students? Temple University, Philadelphia. CNN interview. 2020. http://www.pbs.org/wnet/ amanpour-and-company/video/how-does-pandemic-affect-lowincome-students-nufk5j/.

9. Mohammad H.R., Abdalla M.G., Khaled A. Challenges to Online Medical Education During the COVID-19 Pandemic. Cureus. 2020; 12(7): e8966. doi: 10.7759 /cureus.8966.

10. Emery A., Literte P. Chang E. Developing, implementing, and experiencing an online sociology degree completion program at a large California public university. Cases on critical and qualitative perspectives in online higher education. 2014;182-207. http://doi.org/10.4018/9781-4666-5051-0.ch010.

11. Embracing online teaching during the COVID-19 pandemic. 2020. https://www.ecampusnews.com/2020/03/17/embracing-onlineteaching-during-the-covid-19-pandemic.

12. Fawns T., Jones D., Aitken G. Challenging assumptions about "moving online" in response to COVID-19, and some practical advice. MedEdPublish. 2020; 9 (1): 83. doi: 10.15694/mep.2020.000083.1.

13. Challenges for China's medical education in the coming post-COVID-19 era. National Science Review. 2020;7(10): 1617-1621. https://doi. org/10.1093/nsr/nwaa 168 .

14. Sabzwari s. Rethinking Assessment in Medical Education in the time of COVID-19. MedEdPublish. 2020; 9 (1): 80. doi: 10.15694/ mep.2020.000080.1.

15. Beck R.S., Daughtridge R., Sloane P.D. Physician-patient communication in the primary care office: a systematic review. J Am Board Fam Pract. 2002;15(1):25-38.

16. Gaba D.M. The future vision of simulation in health care. Qual Saf Health Care. 2004; 13(1): i2-i10. doi: 10.1136/qshc.2004.009878.

17. World Health Organization. Telehealth. Analysis of third global survey on eHealth based on the reported data by countries. 2016. https://www. who.int/gho/goe/telehealth.

18. Choi P.J., Oskouian R.J., Tubbs R. Telesurgery: Past, Present, and Future. Cureus 2018;10(5): e2716. doi:10.7759/cureus.2716.

19. Aust M.P. Intensive care unit telemedicine. Am J Crit Care. 2012;21(1):34. doi: $10.4037 /$ ajcc2012416.

20. American Medical Association. AMA encourages telemedicine training for medical students, residents. https://www.ama-assn.org/ press-center/press-releases/ama-encourages-telemedicine-trainingmedical-students-residents.

21. Pottle J. Virtual reality and the transformation of medical education. Future Healthc J. 2019;6(3):181-185. doi: 10.7861/fhj.2019-0036.

22. Chan K.S., Zary N. Applications and Challenges of Implementing Artificial Intelligence in Medical Education: Integrative Review. JMIR medical education. 2019;5(1):e13930. doi: 10.2196/13930.

23. Vaskivska H., Palamar S., Vlasenko 0. Health in the civic students' value system: empirical analysis. Wiadomości Lekarskie. 2019; 72(10): 1947-1952.

24. Kravtsova N.V., Zaychenko G.V.Vprovadzhennya cifrovih instrumentiv u proces navchannya dyscypliny "Pharmacologiya". Suchasni koncepcii vukladannia pryrodnychyh dyscyplin u medycznych osvitnih zakladah [Introduction of digital tools in the process of teaching the discipline "Pharmacology». Modern concepts of teaching natural sciences in medical educational institutions]. HNMU. 2020; 46. (in Ukrainian). 
The studies were carried out as part of the planned research work "New strategy for professional training of education specialist in terms of European integration", (state registration No. 0116U002963) 2016-2021. The study has no external funding.

\section{ORCID and contributionship:}

Halyna O. Vaskivska: 0000-0002-8714-8512 A,B,D,E,F

Svitlana P. Palamar: 0000-0001-6123-241X $X^{A, B, D, E, F}$

Nataliya V. Kravtsova: 0000-0002-4501-1091 ${ }^{A, B, D}$

Olha V. Khodakivska: 0000-0001-6082-3656 ${ }^{\text {B,D }}$

\section{Conflict of interest:}

The Authors declare no conflict of interest.

\section{CORRESPONDING AUTHOR}

Svitlana P. Palamar

Pedagogical Institute of Boris Grinchenko University

18/2 I. Shamo Blvd, 01601 Kyiv, Ukraine

tel: +380507444635

e-mail: svetlana_03@ukr.net

Received: 12.12 .2020

Accepted: 28.04.2021

A - Work concept and design, B - Data collection and analysis, C - Responsibility for statistical analysis,

D -Writing the article, $\mathbf{E}$-Critical review, $\mathbf{F}$ - Final approval of the article 